\title{
STAGING THE NATION: Theatricality in the Law
}

THEATRICAL PRACTICES IN THE COURTROOMS OF THE UNITED STATES AND GREAT BRITAIN ARE EXAMINED IN THIS ARTICLE. THESE PRACTICES ARE VIEWED SPECIFICALLY IN RELATION TO THE CONCEPT OF "STAGING THE NATION." THIS CONCEPT DEALS WITH THE NOTION OF THE NATION AS AN IMAGINARY ENTITY, AN IDEA CONSTRUCTED THROUGH CULTURAL PRACTICES. THEATER PLAYS A STRONG ROLE IN THE WORKINGS OF THE IMACINED NATION. YET, THEATRICAL PRACTICES, OUTSIDE OF THE OFFICIAL THEATER, OPERATE IN MANY OF THE INSTITUTIONS THAT COMPRISE SOCIETY. THE LAW, AS A FOUNDATIONAL INSTITUTION, CONTAINS THEATRICAL ELEMENTS THAT AID IN THE "REHEARSAL" OF THE NATION. EXPLORATIONS OF THE IDEA OF AN IMAGINED NATION, THE REPRESENTATIONS OF NATIONAL IDENTITY IN THE THEATER, AND THE PRESENCE OF THEATRICALITY IN THE COURTROOM ARE SYNTHESIZED IN A STUDY THAT SEEKS TO ELUCIDATE THE POSSIBLE FUNCTIONS AND PURPOSES OF THEATRICALITY IN THE LAW. 


\section{"Nationality is a 'cultural artifact' and can, therefore, be understood in terms of cultural practices."}

Most people, at least in the democracies of the West, would agree that the courtroom contains extreme dramatic potential. The entertainment industry recognizes and exploits this potential with each new television courtroom drama and film it produces. Some of Hollywood's most beloved stars are best remembered for the roles they played as men of the court, such as Gregory Peck's portrayal of Atticus Finch in the film version of To Kill a Mockingbird. The courtroom drama is also no stranger to the stage; its presence there reaches back to the roots of Western theater. Aeschylus staged, to the best of our knowledge, the first trial scene in The Eumenides, and many playwrights since then, such as Arthur Miller in The Crucible, have represented versions of the courtroom in the theater. We seem to recognize the presence of theatrical elements in the courtroom that can be manipulated and exaggerated to produce riveting entertainment. Though we recognize that these elements exist in the actual courtroom, we seldom attempt to articulate what they are beyond the shallow acknowledgement that law and the court can be "dramatic." What, if any, are some of the major theatrical practices and characteristics of the court system in Western democracies such as the United States and the United Kingdom? Furthermore, what are the theatrical elements doing there in the first place? What purpose do they serve?

The legal system as a whole is not an isolated entity. It does not exist for itself but for the nation, as one of its defining institutions. Yet, what is a nation? A good deal of recent thought has explored the view that the nation is an imaginary entity, a collectively constructed concept. According to many thinkers, cultural practices create a sense of national identity and thus construct the idea of the nation. Recent theater criticism, for example, examines the role theater, as a cultural practice, plays in constructing the imaginary nation. The concept of "staging" or "performing" the nation has emerged as a way to describe the theater's contribution to creating, supporting, or criticizing national identities on the stage. Yet, why should the "staging of the nation" be limited to the stage? If, as we seem to think, there are theatrical elements in the courtroom, then we must question what role these elements play in "performing" the nation. A careful examination of the theatrical characteristics of the courtroom, in relation to the concept of "staging the nation," reveals the ways in which these characteristics aid the creation of the concept of the nation.

\section{THE NATION AS AN IMAGINATIVE ENTITY}

Before we can investigate theatricality in the courts, we must attempt to come to grips with the notion of the nation as an imaginative entity. In his work, Benedict Anderson pioneered the view of the nation as a construction. Despite their seeming legitimacy, "nation," "nationality," and "nationalism" usually elude definition. Anderson suggests that the nation is "an imagined political community." $i$ This definition rests, first of all, on Anderson's implicit argument that there is nothing self-evident about a nation. The political boundaries that ascribe nationhood did not exist at the beginning of the world or even the beginning of civilization; rather, nations are created. For Anderson, they are created through an imagined sense of community on the part of the inhabitants of a particular area. Most of the inhabitants of a nation will never meet the other inhabitants; yet, in their minds, they believe there is a connection between them, a common national identity.ii

Anderson not only proposes the understanding of the nation as a created entity, but he also attempts to explain how these imagined communities come to exist. For him, nationality is a "cultural artifact"iii and can, therefore, be 
understood in terms of cultural practices. The cultural practices of print media, he says, have played the largest part in forming imagined communities. The concept of the nation only became possible with the advent of "print capitalism"iv following the invention of the printing press. Newspapers, books, and magazines could be distributed and read on a large scale. Certain ways of thinking were made simultaneously available to all, creating and reinforcing a sense of common identity. ${ }^{\mathrm{V}}$

Anderson's thoughts provide the foundational argument for a view of the nation as a constructed entity. Many other thinkers address aspects of this, exploring and developing them further. One idea developed from Anderson's work emphasizes the importance of the written word, and specifically the narrative form, in constructing the nation. In Nation and Narration, for example, Homi K. Bhabha has collected essays pertaining to "the nation as it is written."vi In these, contributors explore the ways in which authors tell stories about the nation, ranging from Harriet Beecher Stowe's Uncle Tom's Cabin to the works of Virginia Woolf. The collection as a whole contains the notion that the history of the nation is really a history of competing narrative discourses, stories about what the nation is and whence it has come. These narratives are constantly evolving, but through the dominant narratives, we come to collectively imagine our nation and our national identity.

Many people involved in theater studies recognize the importance of Benedict Anderson's views and of subsequent inspired projects, such as Nation and Narration, in so far as how we examine the existence of nations. Yet, as critic S.E. Wilmer points out, these studies have largely ignored the significant role the theater plays in creating, sustaining, or overthrowing national identity.vii The significance of this role is conveyed by William Butler Yeats' query in I938 regarding his 1902 production of Kathleen Ni Houlihan. Reflecting on his life's work, he wonders, "Did that play of mine send out certain men the English shot?" viii referring to the Irish nationalist uprising of Easter I9I6. The question Yeats poses here is not just whether his play inspired the nationalists, but whether it actually created them. Yeats' ultimate question regarding the nature of the relationship between theater and the nation is explored by many theater critics as the notion of "staging the nation."

\section{STAGING THE NATION}

This "staging of the nation" functions on many different levels and in different ways within the theater. Theater critic Loren Kruger focuses on the role the theater, as a cultural and social institution, plays in the construction of nationhood. Kruger argues that in the last quarter of the nineteenth century, politics in England, France, and the United States were conducted on a mass scale. The notion of popular representation became a central concept in the functioning of democratic society, but that popular representation had to cohere and become the popular representation of a nation. Kruger argues that the theater was the place to deal with "making a nation out of an audience, citizens out of spectators." ${ }^{x}$ The actual physical existence of the theater is important to this transformation from audience to nation; hence, "place and occasion thus signify the means and the site on which national prestige - the legitimacy and the renown of the nation in the eyes of its citizens as well as its rivals - is staged, acknowledged, and contested."x The building itself and the physical nature of the theatrical event provide a context for the creation of national identity. The movement in England for a National Theater, begun by Effingham Wilson in I848, exemplifies the importance of the theatrical institution to the nation. ${ }^{x i}$ The National Theater was to be a place that could unify the heterogeneous population of England by representing a version of "Englishness."xii

The content of what is staged also contributes to "staging the nation." In examining how the nation is formed in the United States, S.E. Wilmer cites the Chautauqua movement as one that "helped solidify the notion that America was homogenous and rural, despite (and because of) trends to the contrary."xiii The Chautauquas were annual cultural events dating from the late Igth and early 20 th centuries. They lasted several days and included speeches, 
music, and plays, in which the dominant values expressed were white, Protestant, and capitalist.xiv For example, the extremely successful play, The Melting Pot (1908), insisted that immigrants could be successful in the United States if they abandoned their own cultural values and assimilated into the "dominant" culture. Plays like this one created a sense that the White Anglo-Saxon Protestant (WASP) represented the majority of the United States and its values. ${ }^{\mathrm{xV}}$ In truth, the WASPs were losing their hold on the majority as the country became more diverse, but Chautauqua theater gave the WASPs the hegemony regarding the national identity. They became the dominant representations of "Americans" for many years to come.

In some cases, those involved in the theatrical collaboration engage overtly and directly in the process of constructing national identity. The Field Day Theater Company of Northern Ireland is one such group that, as Marilynn Richtarik puts it, "concerned itself with the relationship between myth and present-day perception, history and politics." $x v i$ The company was founded in I980 in a country where national identity seemed a dire and combustible topic. Their hugely acclaimed production of Friel's Translations explores the ideas of "Irishness" and "Irish" identity.xvii Seamus Heaney, author and member of the Field Day board of directors, later articulated one of the company's major goals: "We would try to redefine what being Irish meant in the context of what has happened in the North over the past twenty years, the relationship of Irish nationalism and culture."xviii The work of the Field Day Company reminds us that the "staging of the nation" is not always a tool used by the power elite to manipulate and indoctrinate the masses. Sometimes, the "staging of the nation" challenges current notions of national identity, re-imagining, as Anderson would see it, the national community.

\section{THEATRICALITY IN THE COURTROOM}

We can see how cultural practices aid in constructing the concept of the nation. The forms of those cultural practices, such as print media and physical theater, help establish a popular identity. The content of the practices, such as the narratives of both literature and theatrical events, also works to imagine the nation and its identity within the stories told. Yet, why should the process of constructing the nation end there? Are there not other aspects of society, other institutions, which are tied firmly to the concept of the nation? Aeschylus was right to portray the founding moment of the world's first democracy as a trial. The law is a key component of the democratic national identity. Democracies generally define themselves by the notion of equality, especially equality in relation to the law, and they offer "justice for all" and a law under which "all are equal." In The Imaginary Institution of Society, Cornelius Castoriadis argues that the significance of societal institutions, such as law, is not only practical but also symbolic. xix The decisions of the court "are symbolic and their consequences are almost entirely so, including the hangman's act which, although eminently real, is also immediately symbolic at another level."xx Hence, the legal system functions on two levels. Although capital punishment is not wholly imaginary, for someone certainly dies, there is also something symbolic about it and about the laws in general, in that they are emblems of national structure, unity, and authority.

Before examining the presence of theatricality in the courtroom, I would like to forestall one possible objection that could be made against relating theatricality to the law. One could argue that the consequences of the theater are imaginary, whereas the consequences of the law are real and, therefore, incomparable to theater. Yet, as Castoriadis argues when discussing symbolism in society, the functioning of something on an imaginative, immaterial level does not negate its material consequences. Theatricality is used here largely as a model for interpreting characteristics or elements of the courtroom in terms of how they function in the imaginative concept of the nation. Using theatricality in this way does not transform the courtroom into theater and render its consequences imaginary. In fact, in a theatrical interpretation of the court, its symbolic characteristics may actually aid its practical concerns. 
Just as Kruger is interested in the physical theater's creation of a performance space, Alastair Blanshard emphasizes the importance of creating a forensic space, a context in which the court proceedings can operate. Blanshard asserts that forensic space can be established either through monumentalisation, in which the "huge scale, rich and elaborate fittings, and authoritarian detailing" of the court buildings "swamp and oppress the viewer," xxi or through ritual, in which performance and props aid in establishing the atmosphere of the court. Although both methods play a role in the modern courtroom, Blanshard focuses on monumentalisation as the defining phenomenon of the court system in modern democracies. He presents the Royal Courts of Justice in London as one example of monumentalisation and examines their High Victorian Gothic architecture and the effect it has of diminishing the individual in its immensity. xxii I can further add my own observations of the "Legal Costume Exhibit" at the courts, in which mannequins in glass cases wear various wigs, robes, and mantles of the English legal profession. Plaques explain the history of these costumes and assert that the "remarkable longevity of some of the forms of dress used in English court is symbolic of the essential continuity of the legal system in this country."

Another example of monumentalisation is the Supreme Court Building in the United States. Blanshard examines the symbolism of the large-scale, neo-classical architecture of the building. He describes the different sculptures on various parts of the building, such as Contemplation of Justice and Authority of Law. The entrance of bronze doors contain eight panels depicting the "evolution" of the law, from the Shield of Achilles through the signing of the Magna Carta to the landmark Marbury v. Madison court case. Even the elevators are decorated with tablets of the Ten Commandments. No detail is overlooked. xxiii

The physical features of both the Royal Courts of Justice and the Supreme Court Building contribute to the "staging of the nation" in several ways. The size and forms of architecture create a sense of power and authority, but perhaps the greater significance lies in the attempt to establish a sense of tradition. The costume exhibit in the Royal Courts of Justice displays the long tradition of the costume in the English court system. The panels on the entrance to the Supreme Court Building attempt to create a narrative of tradition - a progressive story of the law, in which the United States' court system is the triumphant conclusion.

The traditions displayed in these buildings are fabricated to create an authoritative foundation for the nation. The costume exhibit associates the continuous tradition of the legal costume with the "essential continuity" of the English legal system itself, even though there is no evidence that the law has remained continuous just because the costumes have. The entrance panels in the Supreme Court Building take separate historical events and force them into a teleological narrative in which the United States is the end. The tradition invented in both of these buildings grounds the nation in an established moral authority that can be "traced continuously" back through the ages. The narrative of tradition in these buildings gives the individual involved in the court system a sense of his identity and of the significance of his duty as a citizen. Tradition represents this duty as crucial to the existence of the nation; without it, the social fabric would unravel.

As with "staging the nation" in the theater, what is staged is just as important as the site of the staging. When one considers then the content of the court systems, the actual legal proceedings, one again finds the significant presence of a narrative. Blanshard begins his essay with the observation that the courtroom is a place of competing narratives, where one's fate "ultimately depends on the ability to produce the more believable narrative of events." xxiv In his essay "Life is Not a Dramatic Narrative," Alan Dershowitz also recognizes the theatrical element inherent in the production of narratives in the courtroom, the model for which is dramatic. For instance, if a prosecutor is trying to prove that the defendant murdered his business partner, the prosecutor will arrange the facts of the case into a story, informing the jury that the defendant took out a life-insurance pol- 
icy on his partner three days before that partner was murdered. ${ }^{x x}$ What the lawyer hopes is that the jury will interpret his story the way they would a dramatic narrative. Dershowitz quotes Anton Chekhov's advice to S.S. Schovkin to explain the construction of a dramatic narrative: "if in the first chapter you say that a gun hung on the wall, in the second or third chapter it must without fail be discharged."xxvi If a gun appears at the beginning of a drama, someone will be shot by the end. Juries often apply these teleological rules of drama to the narratives of the courtroom; hence, the defendant who took out the life insurance policy must have done so because he was planning to murder his partner.

Dershowitz finds the presence of the dramatic narrative in the courtroom problematic because real life events, to him, are not teleological; they are often meaningless, irrelevant, and coincidental. Warping these events to conform to the paradigm of the dramatic narrative can sometimes force undeserved guilt onto the defendant. Dershowitz has used this argument regarding the unfairness of the dramatic narrative in the courtroom to secure acquittal for several of his clients.xxvii Yet, he does not consider his own success in using this argument in relation to what he finds problematic with the dramatic narrative, though this relation is important. Some "theatricalist" plays consciously point out their own conventions, point out their constructed, illusory nature. In much the same way, Dershowitz introduces his own theatricalist narrative into the courtroom, exposing a particular dramatic technique in the court in order to point out what (for his story) is the "real" situation.

The dramatic narrative at play in the court underpins the court system and, thus, the nation itself. On one level, the dramatic narrative has emerged as a way, in Peter Brook's words, "to formalize the conditions of telling"xxviii in the courts. It gives a structure and a consistency to the kinds of narrative performed in the court. Furthermore, as the implications of Dershowitz's essay show, these narratives are linked to theater for a good reason. Theater seems particularly well suited to pointing out its own presence, to expos- ing many of its illusions, including the contrived nature of the dramatic narrative. The dominance of the dramatic narrative structure in the court leaves inherent space for a meta-narrative, for a story pointing out its own fiction. Much like the conscious agenda of the Field Day Theater Company, which allowed for a certain amount of imaginative freedom in the creation of national identity, the presence of dramatic narrative in the courtroom allows for different narratives to compete with one another, providing the national justice system with a strong but flexible framework.

Perhaps the most significant theatrical element in the democratic court system is representation. In the theater, an actor, a professionally trained representative, represents a character who cannot be there, who cannot speak for himself. In the courtroom, a lawyer, a professionally trained advocate, is permitted to represent his client, to speak for him. ${ }^{\text {xxix }}$ In both cases, the actor and the lawyer take on roles. The actor plays the role of the character he is representing; the lawyer, on the other hand, does not usually pretend to be his client. Rather, the lawyer in court plays a lawyer who is representing his client. The lawyer must roleplay "the lawyer." In the English court system, for instance, the lawyers and the judges wear wigs and robes. At the Royals Courts of Justice, the barristers and the judges wear these costumes in the courtroom. Yet, when outside of the actual courtroom, many of the barristers stand around and chat without wearing their wigs. The costumes, in both the court and the theater, signify their common characteristic of representation: both actors and lawyers step into and out of their roles.

Costumes, however, are not the only means by which men and women play the role of lawyer. They must also act the part. Janet Malcolm reveals yet another layer of this representation in her examination of the side-bar conference in the United States. The side-bar conference is a discussion between the trial judge and the two competing trial lawyers. The two lawyers argue their points in a particular conflict, and the judge adjudicates them. The most important aspect 
of the side-bar conference is that it is conducted out of the hearing of the jury and the spectators, so that they do not know what is being said. The discussion is transcribed, however, and can be referred to at a later time. ${ }^{\mathrm{xxx}}$

Malcolm studied the transcript of the side-bar conferences in MacDonald v. McGinnis, a particularly impassioned murder trial. What surprised her, she says, "was the way everyone's mask suddenly dropped. Out of the hearing of the jury, the lawyers were free to change from dire antagonists to men calmly discussing business. They were free to talk about their competing narratives rather than to enact them. They were like actors sitting around the dressing room putting cold cream on their faces and arguing points of craft and turning to the director to decide who was right." ${ }^{x x x i}$ Malcolm invokes a stereotypical image of actors in order to convey her realization that the lawyers, like actors, are professionals communicating their narratives. In order to do this, the lawyers must play the roles of prosecuting attorney and defending attorney, two titanic arch-rivals. The lawyers themselves, however, usually only feign antagonism. They are really just men or women working together in the same craft. These conferences are held out of the hearing of the jury and spectators in order to maintain the belief in the spectacle, to keep "the illusion-destroying activities of backstage firmly hidden."xxxii

The kind of representation here discussed provides the strongest example of theatrical elements in the law aiding the "staging of the nation." Representation and role-playing in the courtroom "stage" the process of justice itself. The roles taken on by the lawyers lend gravity to the trial proceedings, but they also create a sense of popular representation through a production that can, in the aforementioned words of Kruger, make "a nation out of an audience, citizens out of spectators." xxxiii While it is imperative that the spectators not see the "business" side of the court, it is also of equal importance that this side exist. The right of all democratic citizens to have fair representation from a trained, impartial professional bears out the equality that is so crucial to the democratic national identity.

\section{CONCLUSION}

Politically speaking, the conclusion that the court system is founded in a theatricality that supports the imaginary entity of the nation can be problematic. Does the presence of theatricality in the law support an argument for anarchy, an argument that there is no true authoritative reason for anyone to abide by the law or recognize the government? While one could find anarchistic implications in the presence of theatricality in the law, its existence does more to argue for the advantages of a democratically imagined community. One of the challenges of a democratic nation is to uphold a created national identity whose defining characteristic is its heterogeneity. The presence of the flexible dramatic narrative and universally available representation in the law demonstrates an attempt within the democratic framework to include and accommodate the diverse multitude. This is not to say that theatricality cannot be used to manipulate or intimidate the people in the way, for example, monumental architecture oppresses the viewer with its authority. We need not accept democracy at face-value: we must continue to try to understand its benefits and its injustices. The theatrical model of interpretation deeply penetrates many societal institutions with its understanding that theatricality is not limited to the actual theater. It is also a possible way of examining our lives and the world around us.

\section{ENDNOTES}

i Anderson (1983), I5. ii Anderson (1983), I5-I6. iii Anderson ( 1983 ), I3. iv Anderson (1983), 40. v Anderson (1983), 4I. vi Bhabha (I990), 2. vii Wilmer (2002), I. viii Grote, (2003), 3. ix Kruger (I992), 4. x Kruger (1992), I2. xi Kruger (I992), 85 . xii Kruger (I992), 85-86. xiii Wilmer (2002), II. xiv Wilmer (2002), II. xv Wilmer (2002), I2. xvi Richtarik (I994), IO. xvii Richtarik (I994), 28-29. xviii Richtarik (I994), 68. xix Castoriadis (1987), 115 . $\mathrm{xx}$ Castoriadis (I987), II8. xxi Blanshard (2004), I3. xxii Blanshard (2004), I4. xxiii Blanshard (2004), I6. xxiv Blanshard (2004), I2. xxv Dershowitz (1996), 99. xxvi Dershowitz (1996), 100. xxvii Dershowitz (1996), 100. xxviii Brooks (1996), I9. xxix I would like to acknowledge that I produce this particular notion based on the classroom comments of Dr. Nicholas Ridout. I am taking his suggestion and exploring it in the context of my own topic. 


\section{REFERENCES}

Anderson, Benedict. 1983. Imagined Communities: Reflections on the Origin and Spread of Nationalism. London: Verso.

Bhabha, Homi K. r990. Nation and Narration. London: Routledge.

Blanshard, Alastair. 2004. "The Birth of the Law-Court: Putting Ancient and Modern Forensic Rhetoric in its Place." Oratory in Practice. Michael Edwards and Christopher Reid, eds. Manchester: Manchester University Press.

Brooks, Peter. I996. "The Law as Narrative and Rhetoric." Law's Stories: Narrative and Rhetoric in the Law. New Haven: Yale University Press.

Castoriadis, Cornelius. 1987. The Imaginary Institution of Society. Trans. by Kathleen Blamey. Cambridge: Polity Press.

Dershowitz, Alan M. 1996. "Life is Not a Dramatic Narrative." Law's Stories: Narrative and Rhetoric in the Law. New Haven: Yale University Press.

Grote, Georg. 2003. Anglo-Irish Theatre and the Formation of a Nationalist and Political Culture Between 1890 and 1930. New York: The Edwin Mellen Press.

Kruger, Loren. 1992. The National Stage: Theatre and Cultural Legitimation in England, France, and America. Chicago: University of Chicago Press.

Malcom, Janet. I996. "The Side-bar Conference." Law's Stories: Narrative and Rhetoric in the Law. New Haven: Yale University Press.

Richtarik, Marilynn J. 1994. Acting Between the Lines: the Field Day Theatre Company and Irish Cultural Politics 1980-1984. Oxford: Clarendon Press.

Wilmer, S.E. 2002. Theatre, Society, and Nation: Staging American Identities. Cambridge: Cambridge University Press. 